\title{
PENGARUH PRODUK, HARGA, TEMPAT, PROMOSI TERHADAP KEPUTUSAN PEMBELIAN PIZZA HUT DELIVERY GRESIK
}

\author{
Adel Trudis Nurya Jeni
}

Program Studi Manajamen Fakultas Ekonomi dan Bisnis

Universitas Muhammadiyah Gresik

\begin{abstract}
The purpose of this study was to determine whether the product, price, place and sales promotion variables partially had an influence on the purchasing decision at Pizza Hut Delivery Gresik. The type of data used is primary data. Primary data was obtained through direct interviews with the Pizza Hut Delivery Gresik Manager. The data analysis technique used is multiple linear regression whose purpose is to calculate the magnitude of the regression coefficient which will show the magnitude of the influence of the independent variables consisting of product variables, prices, places, and sales promotions on purchasing decisions. Based on the results of this study indicate that product variables, prices, places, and sales promotions partially influence the purchase decision variables.
\end{abstract}

Keywords: products, prices, places, promotions, and purchasing decisions

\section{PENDAHULUAN}

Kondisi bisnis saat harus menggunakan konsep pemasaran untuk mencapai kesuksesan bagi perusahaan. Pemasaran berawal dari suatu ide untuk mencapai laba penjualan, perusahaan harus dapat memahami konsumen beserta keinginannya. Setiap perusahaan mempunyai strategi dalam berusaha. Bentuk strategi akan berbeda-beda antar perusahaan, hal ini dilakukan untuk mencapai tujuan perusahaan.

Perusahaan harus membagi pasarnya ke dalam segmen-segmen atau kelompok konsumen serta menentukan keinginan dari masingmasing segmen tersebut. Tjiptono dan Chandra (2012;406) menyatakan tujuan penjualan yang dilakukan oleh perusahaan secara garis besar terdiri dari empat macam yaitu (a) tujuan yang dirancang untuk menekankan penambahan distributor/pelanggan baru, (b) tujuan yang mengarahkan pada upaya menjalin kerjasama dengan para distributor dalam rangka menerapkan strategi pemasaran, (c) tujuan penjualan yang dirancang mempertahankan posisi penjualan efektif, (d) tujuan dirancang untuk meningkatkan volume penjualan.

Restoran cepat saji adalah salah satu dari restoran yang tidak membutuhkan waktu yang lama dalam hal penyajian kepada konsumen. Banyak contoh restoran cepat saji yang berkembang tersebut adalah Pizza Hut Delivery. Industri makanan dengan jasa Delivery belakangan ini banyak diminati oleh konsumen. Hal ini dikarenakan semakin banyaknya aktifitas masyarakat masa kini telah tinggi, waktu lebih sedikit karena banyak kesibukan, mobilitas semakin tinggi dan kebutuhan semakin banyak.

Salah satu perusahaan yang memberi fasilitas delivery yaitu PHD (Pizza Hut Delivery) yang berada di bawah naungan PT. Sari Melati Kencana. Perusahaan ini bergerak di bidang kuliner, menjual berbagai macam produk seperti pizza, pasta, 
makanan ringan dan minuman. PHD dalam penjualan produk menerapkan sistem pengambilan produk di outlet langsung (takeaway) dan sistem pengantaran produk kerumah customer (delivery).

Pizza Hut Delivery butuh sebuah strategi pemasaran yang tepat untuk memenangkan hati persaingan. Masih ada beberapa faktor yang mempengaruhi keputusan pembelian yaitu bauran pemasaran. Assauri $(2011 ; 198)$ mengungkapkan bahwa salah satu strategi pemasaran yaitu produk (product), harga (price), tempat (place), promosi (promotion). Produk merupakan suatu manfaat atau nilai yang ditawarkan perusahaan kepada konsumen. Kualitas produk menurut Kotler dan Amstrong (2012;62) adalah kemampuan suatu produk untuk menunjukan berbagai fungsi seperti ketahanan, ketepatan, kemudahan dalam penggunaan. Harga yakni alat pengukur dasar suatu sistem ekonomi karena harga mempengaruhi alokasi faktor-faktor suatu produksi. Harga didasarkan pada nilai bahwa seseorang atau pengusaha bersedia melepaskan barang atau jasa yang dimiliki kepada pihak lain (Kotler dan Amstrong, 2012;70).

Tempat atau lokasi merupakan pendistribusian yang dapat diartikan sebagai kegiatan pemasaran yang berusaha memperlancar dan mempermudah penyampaian barang dan jasa dari produsen kepada konsumen, sehingga penggunaannya sesuai dengan yang diperlukan (jenis, jumlah, barang, harga, tempat dan saat dibutuhkan)(Oentoro, 2010;207). Promosi juga merupakan hal yang sangat penting dalam mencari perhatian konsumen. Promosi juga suatu usaha dari pemasar dalam menginformasi dan mempengaruhi pihak lain sehingga tertarik untuk melakukan transaksi atau pertukaran produk barang atau jasa yang dipasarkannya (Oentoro, 2010;173).

Demi menarik konsumen, PHD menawarkan produk dengan berbagai macam varian dan dengan fasilitas mengantarkan pizza langsung kepada pembelinya. Tetapi kondisi pasar yang semakin banyak produk-produk pizza baik jenis lokal maupun berasal dari Negara lain, dengan konsep strategi pemasaran yang beragam sehingga menarik minat membeli khalayak umum. Semakin beragam produk pizza dipasaran yang ditawarkan oleh kompetitor membuat penjualan PHD khususnya di outlet Gresik mengalami penurunan. Berikut volume penjualan PHD take away maupun delivery dari tahun 2015 sampai dengan tahun 2017, Penjualan tahun 2015 mencapai Rp 1.367.000.000,- penjualan pada tahun 2016 mencapai Rp 1.329.000.000,dan penjualan pizza hingga akhir tahun 2017 mencapai Rp 1.287.000.000,-. Hal ini menunjukan jika situasi pasar semakin kompleks dengan pesaing yang semakin ketat, baik dari produsen lain yang mulai memenuhi pasar makanan Indonesia.

Mengingat pentingnya aktifitas pemasaran serta keinginan mengenai efektifitas pemasaran yang dilakukan oleh PHD outlet Gresik dalam menarik konsumen untuk membeli produk pizza tersebut untuk meningkatkan penjualan pizza, dan dari latar belakang tersebut di atas, maka dilakukan penelitian mengenai

"PENGARUH

PRODUK, HARGA, LOKASI, PROMOSI TERHADAP KEPUTUSAN PEMBELIAN PIZZA HUT DELIVERY" dengan tujuan untuk mengetahui pengaruh secara parsial antara harga, produk, lokasi dan 
promosi sebagai variabel terikat dengan keputusan pembelian sebagai variabel tidak terikat.

\section{KAJIAN PUSTAKA \\ Pemasaran}

Pemasaran adalah bagian dari ekonomika serta memiliki peranan yang sangat penting dalam kegiatan ekonomi dan merupakan salah satu kegiatan pokok yang dilakukan oleh pengusaha dalam menjalankan usahanya untuk mempertahankan kelangsungan hidupnya, untuk berkembang dan mendapatkan laba. Menurut Kotler dan Keller (2009;5) pemasaran adalah mengidentifikasi dan memenuhi kebutuhan manusia dan sosial. Dengan definisi yang baik dan singkat dari pemasaran yaitu memenuhi kebutuhan dengan cara yang menguntungkan. Menurut Deliyanto (2012;13) manajemen pemasaran dapat didefinisikan sebagai proses penganalisaan, pelaksanaan, dan pengawasan, program-program yang bertujuan menimbulkan pertukaran dengan pasar yang dituju dengan maksud untuk mencapai tujuan perusahaan.

\section{KONSEP PEMASARAN}

Dalam konsep pemasaran, seseorang atau pengusaha sudah mulai mengenal bahwa pemasaran merupakan faktor yang penting untuk mencapai keberhasilan bagi perusahaan akan mengetahui cara yang terlibat di dalamnya. Menurut Setyaningrum $(2015 ; 14)$ para produsen harus menganilisis terlebih dahulu kebutuhan para pelanggan, kemudian membuat keputusan yang dirancang untuk memuaskan kebutuhan tersebut. Konsep pemasaran menyangkut:

1. Memfokuskan pada kebutuhan konsumen.

2. Mengintegrasikan semua kegiatan organisasi,termasuk memproduksi untuk memuaskan kebutuhan.

3. Memperoleh keuntungan jangka panjang melalui kepuasan atas kebutuhan konsumen.

Menurut Kotler dan Keller (2009;20) konsep pemasaran beranggapan bahwa kunci untuk mencapai tujuan organisasi adalah menjadi lebih efektif daripada pesaing dalam menciptakan, menghantarkan, dan mengkomunikasi nilai pelanggan yang lebih baik kepada pasar sasaran yang dipilih.

\section{Keputusan Pembelian}

Keputusan pembelian pada umumnya memiliki peran yang sangat penting. Para penjual dapat memahami konsumen dengan baik melalui pengalaman menjual produk secara langsung kepada mereka. Namun perkembangan perusahaan yang semakin besar dan pasar yang kian semakin luas, para pengambil keputusan pemasaran kehilangan kontak dengan konsumen. Menurut Suryani (2013;11) keputusan pembelian adalah keputusan yang diambil individu karena stimulasi (rangsangan), baik yang berasal dari luar individu maupun hal-hal yang ada pada individu sendiri.

\section{Produk}

Produk merupakan nilai yang diciptakan dan ditawarkan oleh perusahaan untuk memenuhi kebutuhan pelanggan. Selain untuk memenuhi kebutuhan dan keinginan, produk juga mampu untuk menjadi solusi bagi pelanggan. Produk adalah barang atau jasa yang dapat diperjual-belikan. Setyaningrum $(2015 ; 14)$ produk yakni segala sesuatu yang ditawarkan pada masyarakat guna dilihat, dipandang, dibeli atau dikonsumsi. 


\section{Harga}

Harga merupakan elemen penting dalam strategi pemasaran dan harus senantiasa dilihat dalam hubungannya dalam strategi pemasaran. Harga merupakan satu-satunya unsur bauran pemasaran memberikan pemasukan atau pendapatan bagi perusahaan. Menurut Oentoro $(2010 ; 149)$ harga adalah suatu nilai tukar yang bisa disamakan dengan uang atau barang lain untukmanfaat yang diperoleh dari suatu barang atau jasa bagi seseorang atau kelompok pada waktu tertentu dan tempat tertentu.

\section{Tempat}

Tempat merupakan salah sau variabel yang penting untuk menghasilkan volume penjualan. Tempat mengacu pada suatu tempat bagi pelanggan untuk lebih mudah mengaksesnya dan mendapatkannya. Tempat identik dengan saluran distribusi. Oentora $(2010 ; 207) \quad$ saluran distribusi merupakan jalan atau rute yang dilalui oleh produk mulai dari produsen sampai ke tangan pelanggan akhir. Setyaningrum $(2015 ; 14)$ menyatakan ada tiga jenis yang mempengaruhi tempat, yaitu :

1. Konsumen mendatangi pemberi jasa (perusahaan): apabila keadaannya seperti ini maka lokasi menjadi sangat penting. Perusahaan sebaiknya memilih tempat yang dekat dengan konsumen sehingga mudah dijangkau dan strategis.

2. Pemberi jasa mendatangi konsumen, jadi lokasi tidak terlalu penting, tetapi yang harus diperhatikan adalah penyampaian jasa harus tetap berkualitas.

3. Pemberi jasa dan konsumen tidak bertemu secara langsung: berarti penyedia layanan/ jasa dan konsumen berinteraksi melalui saran tertentu seperti telepon, komputer, atau surat. Lokasi menjadi sangat tidak penting selama komunikasi di antara kedua pihak dapat terlaksana.

\section{PROMOSI}

Promosi adalah berbagai kegiatan perusahaan untuk berkomunikasi dan memperkenalkan produk pada pasar sasaran. Promosi adalah variabel marketing mix yang membutuhkan biaya cukup besar. Menurut Setyaningrum $(2015 ; 14)$ promosi adalah berbagai kegiatan perusahaan untuk berkomunikasi dan mengenalkan produk pada pasar sasaran. Dibutuhkan strategi untuk mengombinasi metode individual, seperti iklan, promosi penjualan, dan promosi individual dalam kampanye yang terkoordinasi. Strategi promosi juga harus disesuaikan saat prosuk tersebut bergerak dari tahap dini ke tahap selanjutnya dalam hidupnya.

\section{KERANGKA KONSEPTUAL}

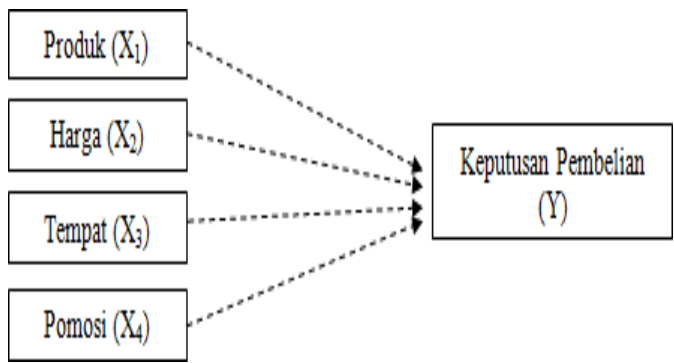

Berdasarkan rumusan masalah, tujuan penelitian dan landasan teori, maka hipotesis yang diajukan dalam penelitian ini adalah sebagai berikut:

1. Produk berpengaruh terhadap keputusan pembelian Pizza Hut Delivery outlet Gresik.

2. Harga berpengaruh terhadap keputusan pembelian Pizza Hut Delivery outlet Gresik.

3. Tempat berpengaruh terhadap keputusan pembelian Pizza Hut Delivery outlet Gresik. 
4. Promosi berpengaruh terhadap keputusan pembelian Pizza Hut Delivery outlet Gresik.

\section{METODE PENELITIAN}

Jenis penelitian ini adalah kuantitatif. Penelitian kuantitatif pada umumnya dilakukan pada sampel yang diambil secara random, sehingga kesimpulan hasil penelitian dapat di genaralisasi pada populasi di mana sampel tersebut diambil. Penelitian ini menggunakan analisis regresi linier berganda, metode ini digunakan untuk mengetahui hubungan menyeluruh tentang hubungan antara variabel harga, produk, tempat, dan promosi terhadap keputusan pembelian pada Pizza Hut Delivery Gresik dengan persamaan sebagai berikut :

$Y=a+b_{1} X_{1}+b_{2} X_{2}+b_{3} X_{3}+b_{4} X_{4}+e_{1}$

\section{Hasil dan Pembahasan}

Hasil persamaan regresi linier berganda diatas dapat dijelaskan sebagai berikut:

1. Produk $\left(\mathrm{X}_{1}\right)$ diperoleh $\mathrm{t}_{\text {hitung }}$ sebesar 2,035>t tabel sebesar 1,985. Dengan signifikan sebesar $5 \%$ maka Ho ditolak dan $\mathrm{Ha}$ diterima. Hal ini berarti variabel $\operatorname{Produk}\left(\mathrm{X}_{1}\right)$ berpengaruh signifikan terhadap Keputusan Pembelian Pizza Hut Delivery Gresik.

2. Harga $\left(\mathrm{X}_{2}\right)$ diperoleh $\mathrm{t}_{\text {hitung }}$ sebesar $2,794>t_{\text {tabel }}$ sebesar 1,985. Dengan signifikan sebesar 5\% maka Ho ditolak dan Ha diterima. Berarti variabel harga $\left(\mathrm{X}_{2}\right)$ berpengaruh signifikan terhadap Keputusan Pembelian Pizza Hut Delivery Gresik.

3. Tempat $\left(X_{3}\right)$ diperoleh $t_{\text {hitung }}$ sebesar 3,327 > $t_{\text {tabel }}$ sebesar 1,985. Dengan signifikan sebesar 5\% maka Ho ditolak dan $\mathrm{Ha}$ diterima. Berarti variabel tempat $\left(\mathrm{X}_{3}\right)$ berpengaruh signifikan terhadap Keputusan Pembelian Pizza Hut Delivery Gresik.

4. Promosi $\left(\mathrm{X}_{4}\right)$ diperoleh thitung sebesar 2,636>t tabel sebesar 1,985. Dengan signifikan sebesar 5\% maka Ho ditolak dan $\mathrm{Ha}$ diterima. Berarti variabel promosi $\left(\mathrm{X}_{4}\right)$ berpengaruh signifikan terhadap Keputusan Pembelian Pizza Hut Delivery Gresik.

\section{Interprestasi Hasil Analisis}

1. Hasil penelitian menunjukan bahwa nilai t hitung/t penelitian sebesar $(2,035)>$ nilai $t_{\text {tabel }}$ sebesar $(1,985)$ sehingga Ho ditolak dan Ha diterima.

2. Hasil penelitian menunjukan bahwa nilai t hitung/t penelitian sebesar $(2,794)>$ nilai $t_{\text {tabel }}$ sebesar (1,985) sehingga Ho ditolak dan $\mathrm{Ha}$ diterima. Dapat disimpulkan bahwa terdapat pengaruh harga terhadap keputusan pembelian.

3. Hasil penelitian menunjukan bahwa nilai t hitung/t penelitian sebesar $(3,327)>$ nilai $t_{\text {tabel }}$ sebesar $(1,985)$ sehingga Ho ditolak dan $\mathrm{Ha}$ diterima. Dapat disimpulkan bahwa terdapat pengaruh tempat terhadap keputusan pembelian.

4. Hasil penelitian menunjukan bahwa nilai t hitung/t penelitian sebesar $(2,636)>$ nilai $t_{\text {tabel }}$ sebesar $(1,985)$ sehingga Ho ditolak dan Ha diterima. Dapat disimpulkan bahwa terdapat pengaruh tempat terhadap keputusan pembelian.

\section{Kesimpulan}

Berdasarkan hasl pengolahan data dan analisis yang telah dilakukan pada bab-bab sebelumnya, hasil penelitian ini dapat disimpulkan sebagai berikut : 1. Produk berpengaruh signifikan 
terhadap Keputusan Pembelian pada Pizza Hut Delivery Gresik. Semakin baik produk yang dimiliki PHD maka keberhasilan perusahaan semakin tinggi.

2. Harga berpengaruh signifikan terhadap Keputusan Pembelian di Pizza Hut Delivery Gresik. Semakin baik harga yang diberikan PHD maka keberhasilan perusahaan semakin tinggi.

3. Tempat berpengaruh signifikan terhadap Keputusan Pembelian di Pizza Hut Delivery Gresik. Semakin baik tempat yang dimiliki PHD maka keberhasilan perusahaan semakin tinggi.

4. Promosi berpengaruh signifikan terhadap Keputusan Pembelian di Pizza Hut Delivery Gresik. Semakin baik promosi yang dimiliki PHD maka keberhasilan perusahaan semakin tinggi.

\section{Rekomendasi}

Berdasarkan hasil analisis, pembahasan, dan kesimpulan penelitian, maka rekomendasi yang peneliti berikan sebagai berikut:

1. Untuk pihak perusahaan harus tetap menjaga kualitas produk dan mempertahankan cita rasa dalam pembuatan pizza agar konsumen tetap bertahan untuk tetap membeli produk Pizza di PHD Gresik.

2. Dalam penentuan harga pihak perusahaan harus bisa menganalisis dan menetapkan harga yang tepat untuk konsumen. Karena harga merupakan penentuan konsumen dalam melakukan pembelian.

3. Perusahaan harus menentukan tempat dalam melakukan penjualan, di mana PHD termasuk tempat yang strategis tetapi tempat yang digunakan terlalu ke dalam atau terlalu jauh dari jalan raya dan tempat yang kecil sehingga konsumen yang berasal dari luar kota terlalu sulit untuk menemukannya.

4. Pihak perusahaan tersebut harus tetap mempertahankan dan terus meningkatkan cara promosi produk pizza ini dalam tanyangan yang menarik dan dengn komunikasi yang baik agar konsumen lebih tertarik untuk membeli produk pizza.

\section{DAFTAR PUSTAKA}

Assauri, Sofjan. (2011). Manajemen Pemasaran. Cetakan ke-11. Jakarta: Penerbit PT. RajaGrafindo Persada.

Kotler, Philip, dan Gerry Armstrong. (2012). Prinsip-prinsip Pemasaran. Edisi Keduabelas. Jakarta: Penerbit Erlangga.

Kotler, Phillip dan Keller. (2009). Manajemen Pemasaran. Jakarta: Penerbit Erlangga.

Oentoro, Deliyanto. (2010). Manajemen Pemasaran Modern. Yogyakarta: LaksBang PRESSindo.

Setyaningrum, Ari, Jusuf Udaya dan Efendi. (2015). Prinsip-Prinsip Pemasaran, Yogyakarta: Andi.

Sugiyono. (2016). Metode Penelitian Pendidikan. Bandung: Alfabeta.

Tjiptono, Fandy, dan Gregorius Chandra. (2012). Pemasaran Strategik. Edisi Kedua. Yogyakarta: CV. Andi. 